\title{
Shifting Between Writing Systems: Some Linguistic Remarks and Typological Observations
}

\author{
Edoardo Scarpanti \\ Accademia Nazionale Virgiliana, Mantova, Italy \\ E-mail: edoardo.scarpanti@gmail.com
}

Received: January 10, 2021 Accepted: February 5, 2022 Published: February 13, 2022

doi:10.5296/ijl.v14i1.19455

URL: https://doi.org/10.5296/ijl.v14i1.19455

\begin{abstract}
Just like human languages, also writing systems tend to change in diachrony, and sometimes they are substituted by new ones, in a process that we can call writing systems shift. The way this process takes place is determined by many conditions, which are here briefly described and discussed. Some recurrent facts suggest that a script shift is a linguistic phenomenon which is strongly marked, and which needs both a strong motivation, inside the speaking community, and a strong motivator, outside the same community. Despite some previous thoughts, in fact, it's possible that choosing a new writing system is not simply the consequence of an evolution towards a "better" or "more adapt" system, but rather a more general matter of linguistic identity, which involves the whole speaking community.
\end{abstract}

Keywords: Writing systems, Script, Alphabet, Linguistic community, Language change, Linguistic interference, Sociolinguistics, Applied linguistics, Diachronic linguistics

\section{Introduction: A Rather Common Metalinguistic Idiom, and Some Preliminary Remarks}

If we consider a single linguistic community in any moment of its history, we could be quite sure that the possibility that the community itself undergoes a full substitution of language - a phenomenon which is known as language shift - is generally quite low. As a matter of fact, abandoning a language for another one is a rather demanding task, and a process which requires both a strong motivation within the community of speakers and a relatively long period of time. Normally, such a process will take at least one or two generations to be fully achieved, and it will probably face major resistances at many levels of the linguistic community, as largely discussed, for instance, by many scholars as Labov (2001), Karan (2011), or - for historical languages - Witzel (2001). In fact, as we know quite clearly, the role of language in creating and maintaining a shared social identity is an extremely common element in human history. Thus, a large linguistic code switching is usually accompanied by a 
parallel identity switching, whose full acceptance, or complete refusal, may depend on many - and not only linguistic - factors.

Nevertheless, it's worth noting that changing and switching a written code, rather than simply a verbal one, sometimes appears to be a still more demanding task, and a less common and frequent one as well. In some cases, where the substituted writing code completely disappears, this process could be very close to the one that affects human languages and which is commonly known as language death (cf. Thomason \& Kaufman, 1988; Wurm, 1991; Romaine, 1994; Crystal, 2002; Mufwene, 2008). For instance, amongst the various dead and disappeared scripts of the Antiquity we can observe the interesting case of the Aegean area, where a certain amount of writing systems did vanish long before the adoption of a completely different one: thus, Cretan hieroglyphic, Linear A, Linear B, and Cypro-Minoan apparently 'died' without leaving a descendent, till the subsequent and fully unrelated 'birth' of the Greek alphabet. So, the complex phenomenon of writing system shift, which has been quite commonly observed by linguistics scholars, maybe deserves some further remarks and observations.

Anyway, before considering the issues that are linked to the specific object of this paper, we could briefly observe a quite common idiom, which appears to carry out a specific and not unimportant metalinguistic meaning, whose English most popular version is the following: that's (all) Greek to me. How should we interpret it?

As we know, for a speaker who begins the formal study of a foreign language that requires the parallel learning of a writing system, which appears to be different from the one of his mother language, one of the major difficulties to overcome is precisely the correct acquisition of the new graphic system. As a matter of fact, if we agree that 'language is not a purely technical tool; [but] it is a cultural artifact created within specific sociocultural and historical contexts, and thus carries the characteristics of these contexts' (Vygotsky, 1978; Tsui \& Tollefson 2007, p. 2), then we must consider that writing system is a crucial part of that same context. For example, in the case of an Italian speaker who studies Chinese language as L2, the high quantitative consistency of the graphemic set of Chinese could actually be considered an objective difficulty by the learner himself (even if, in reality, the extreme graduation in learning the graphemes and the easy syntax of the signs appear to be strong advantages in L2 acquisition, not to mention the functional advantages of the application of such a system to an isolating language, with musical accent and a high level of homophony). It is at this point evident that, for an L2 learner, a new writing system often represents more a perceived - and therefore psychological - obstacle than an objective difficulty.

A single marginal linguistic fact, such as the English idiomatic phase mentioned above (i.e. that's (all) Greek to me), would seem to confirm the centrality of the perception of the obstacle of writing system difference in the whole learning process, and perhaps a single and somehow trivial lexical observation could better clarify the whole mechanism. The phenomenon which has to be explained here deals with the semantic value of a specific range of idioms, or polyrhematic expressions. As a matter of fact, many different and genetically unrelated languages share some structurally similar idiomatic expressions, which are meant to 
indicate something that is 'not clear', 'not easy to understand', or even 'not understandable at all' for the speakers. The expression recurs in semantically equivalent patterns, which could be simplified as follows: 'This is $\mathrm{X}$ to me', where ' $\mathrm{X}$ ' is a glottonym directly related to a specific foreign language, and where the semantic value of the whole sentence is 'This is too difficult to me', or simply 'I don't understand it'. For instance, in Italian is quite common the expression per me è arabo, i.e. 'it's Arabic to me', whereas in many other languages different but clearly similar phrases seem to occur. As has been already noticed (Rosenberg 1979), many of the idiomatic expressions, which share this common semantic value and this structure, tend to choose a number of quite recurring glottonyms, namely Chinese, Greek, and Arabic. Apparently, such a lexical choice could be simply explained by picking the name of a language that is perceived as difficult, in different degrees. So, an English speaker would say it's Greek to me, but an Italian one would rather formulate a sentence which means it's Arabic to me. Amongst a very wide range of possible glottonyms, sometimes the choice of Greek, Chinese or Arabic could also share a cultural strengthening element, which is surely the case for English idiom it's Greek to me, that finds a direct source in Shakespeare's Julius Caesar, where Casca uses this particular expression while talking with Cassius, in a metalinguistic joke which merges both its denotative and connotative semantic meanings:

[Cassius]: Did Cicero say any thing?

[Casca]: Ay, he spoke Greek.

[Cassius]: To what effect?

[Casca]: Nay, an I tell you that, I'll ne'er look you i' the face again: but those that understood him smiled at one another and shook their heads; but, for mine own part, it was Greek to me.

The same idiom did really exist in Latin itself, and we can trace it in some of the marginal notes left by medieval scribes, when they weren't able to understand a passage in the source that they had to copy: Graecum est, non legitur, i.e. "that's Greek, it's impossible to read it". But, if we consider with attention some of the most relevant attested varieties of this same idiomatic expression among main European languages, we'll surely notice something that goes beyond the simple choice of a glottonym which refers to 'a language that is perceived to be difficult to understand'. Some of these idioms are listed below, under three different groups: (A) those referring to Chinese; (B) those referring to Greek; and (C) those referring to other languages.

(A) referring to Chinese:

Dutch, Dat is Chinees voor mij, 'It's Chinese to me'; Estonian, See on mulle hiina keel, 'id.'; Hungarian, Ez nekem kínai, 'id.'; Lithuanian, Tai man kaip kinu kalba, 'id.'; French, C'est du chinois, 'It's Chinese'; Polish, To dla mnie chińszczyzna, 'id.'; Spanish, Está en

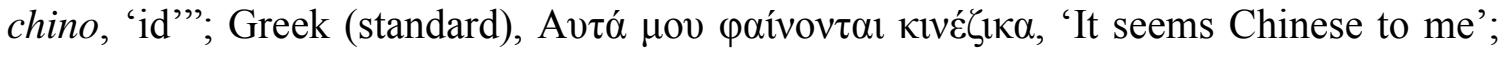
Romanian, Parcă e chineză, 'id.'; German, Spreche ich chinesisch?, 'Do I speak Chinese?'; Albanian, Mos fol kinezce, 'Don't speak Chinese'; Arabic (standard), Yatahaddat bil-lugiah aș-Șinīyah, 'He’s speaking Chinese'. 
(B) referring to Greek:

English, It's Greek to me; Afrikaans, Dis Grieks vir my, 'id.'; Portuguese, Isto para mim é grego, 'id.'; Swedish, Det är rena grekiskan, 'It's all Greek'.

(C) referring to other languages:

Italian, Per me è arabo, 'It's Arabic to me'; Finnish, Täyttä hepreaa, 'It's Hebrew'; Icelandic, petta er hebreska fyrir mér, 'That's Hebrew to me'; Egyptian Arabic,

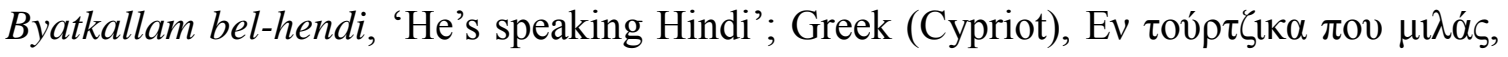
'Are you speaking Turkish?'.

How did all these forms develop? And, in which way are they related to each other? In some cases, maybe the attested idioms in an European language could be the result of a structural calque from the same widely known Latin formula that we have already quoted before, i.e. Graecum est, non legitur, especially if we consider the phrases listed above under (B). In these cases, the original expression could have undergone a loss of its second portion, i.e. non legitur. But in the case of Chinese (A), such a chronologically distant source is not so easy to be found. In some other cases, a different cultural, historical, or economical link could maybe explicate the linguistic choice of the single glottonyms. This may be easily proven for the 'Greek group' (B) and for some examples from group (C), but it appears to be much more difficult to understand if we look directly at the 'Chinese group' (A): in this case, even if we could think of some cultural and historical contacts, for instance, between China and the Netherlands, or China and France, on the other hand we would find it less easy to link China with Lithuania or with Albania.

The hypothesis of an important role, in the choice of the glottonyms among these idioms, of the writing systems of the different languages perhaps is more striking. In fact, the great majority of the examples contained in group (A) oppose Chinese, with its own logographic system, to languages which use Latin-derived alphabets. In the same way, also in the case of Greek and standard Arabic there is a strong difference in writing systems with the compared term, that is still Chinese. Even in the group (B), which refers to Greek for the matching, we can observe the opposition of the Latin-derived alphabet to the Hellenic one. In the same way, in group $(\mathrm{C})$ there is a fairly regular opposition between different writing systems, namely: Latin-derived alphabet (for Italian) vs. Arabic abjad, Latin-derived alphabet (for Finnish) vs. Hebrew abjad, Arabic abjad vs. devanagari script (for Hindi), and finally Greek alphabet (in Cyprus) vs. Arabic-derived abjad (for Turkish, before the script reformation of 19th Century). Moreover, there are some very interesting cases, which are listed under the following letter (D), where the idiomatic expression has been constructed by explicitly considering and quoting the perceived difficulty posed by a foreign writing system, and not by the language itself.

(D) referring to a different writing system:

Latvian, Tā man ir ķīniešu ābece, 'That's Chinese alphabet'; Russian, Это для меня китайская грамота, 'That's Chinese writing to me'; Syrian Arabic, Yahki Karš̄uni, 'He's speaking Syriac (referring to the script)'. 
If we consider the above discussed data, maybe we could conclude that, in all the quoted idioms, the semantic value of the metalinguistic assertion this is $X$ to me, meaning 'this is unintelligible to me', is directly caused by considering the obscurity and unintelligibility of a foreign writing system, and not (or even not primarily) the difficulty of understanding a foreign spoken language. And if this true, then we should consider this fact as a proof of the striking importance of the difference in writing systems - which we call allography - in creating and maintaining parallel differences at various levels, such as linguistic identity, linguistic distance perception, and cultural differences in general between two or more linguistic communities.

\section{On Writing Systems Shift Typology}

Now that we have observed a single case, that could demonstrate the great importance of writing systems differences in creating a linguistic and cultural identity, we can also try to understand how exactly a writing systems shift is able to create, to intensify and to magnify the perception of relative differences and distance among spoken languages, and we'll try to observe this issue just as a particular case of the more general phenomenon of language shift (on which, cf. Gelb, 1952), by adopting the general and common instruments of linguistic analysis, which shows a long-time interest on the study of writing systems (see e.g. Cardona 1986, 1991; Olson 1994; Coulmas 1996, 2003, 2020; Daniels \& Bright, 1996; Valeri, 2001; Iannàccaro, 2005; Arcangeli, 2007, pp. 29-50; Haarmann, 2002; Rogers, 2005; Baines, Bennet \& Houston, 2008; Sanga, 2009; Banfi \& Grandi, 2012; Sampson, 2016; Cotticelli-Kurras \& Rizza, 2017; Daniels, 2018; Meletis, 2020; and the rich bibliography of Ehlich et alii, 1996). By doing so, even if the details of writing system change could be quite complicated, and not always easy to be thoroughly investigated, we should anyway be able to underline some recurrent trends that regulate the entire process.

A writing system shift (or script shift) occurs when, in a precise moment of its history, a single linguistic community abandons a previously used script, in order to adopt a new one. It should be self-evident, that changing such a symbolic structure is a decision which is not without consequences, and a fact that is linguistically marked, sometimes traumatic, and not easy to achieve. In general, it's maybe important to investigate, as a consequence, what could cause such a dramatic shift in the linguistic behavior of the entire community, and how the shift concretely takes place (Coulmas, 1996, p. 368; Daniels \& Bright, 1996, pp. 97-311; Baroni, 2011; Neef, 2015). Anyway, a rather long-established communis opinio about writing system shift, is that this kind of change does occur only when some very crucial linguistics issues strongly recommend the adoption of a 'more adapt' and 'more useful' script, with regards to a single community (for an influential example of this 'evolutionary' approach, see e.g. Gelb, 1952). But, as we'll try to see in brief, in reality this was a quite uncommon and extremely rare case, while the normal and unmarked way of shifting scripts follows rather different and peculiar rules (cf. Baines, Bennet \& Houston, 2008; Bassetti, 2013; Gnanadesikan, 2021).

In many cases, the linguistic community simply adopts a writing system which was already in use in a different group of speakers, and we could call this kind of phenomenon an exogenous 
script shift. That's the case, for instance, of communities in ancient Italy - like Celts, or Etruscans - that gradually abandoned their previous writing systems, in order to adopt the Latin one, as a result of the Roman expansion in the peninsula. A similar case is the one of the dramatic diffusion of Arabic abjad, from the 8th Century A.D., when a fast-spreading exogenous script shift took place even in those areas where a parallel language shift into Arabic did not happen at all, i.e. in Anatolia, in Persia, or in Northern India (Coulmas, 1996, pp. 18-23; Daniels \& Bright, 1996, pp. 559-568). In the case of Arabic abjad, the script shift apparently followed the same steps that are usually observed in spoken language shift, with an initial and progressive decay of the previous system, and then a subsequent erosion that finally leads into the script substitution. Thus, the phenomenon itself could be fully considered within the wider contest of language interference (Gusmani, 1987; Thomason \& Kaufman, 1988; Thomason, 2001). Moreover, in these examples a very strong cultural - and namely religious - issue did interfere with the bare linguistic behaviors of the community: that is, the large spread of Islam, which was also symbolically and visually related to the diffusion of the Arabic script.

A second phenomenon, which we could call endogenous script shift, also occurs, and maybe it happens to be more interesting than the first one from a linguistic point of view. In this case, a single community freely decides to change its own script, without being pressed by any external influence in political, military, religious, or even barely cultural terms. We could think, as we already said, to what happened when the Ancient Greek speaking communities, which had previously used Linear B script between the end of the 2nd and the beginning of the 1st millennium B.C., quickly developed a completely different system - i.e. the first alphabet in history, mainly based on Phoenician abjad - and then completely adopted it during the 7th Century B.C. (Chadwick, 1990; Woodard, 1997; Ghinatti, 1999; McLean, 2002; Consani, 2003). In the same way, for example, the ancient ideographic system of Egyptian hieroglyphs was abandoned in favor of Coptic alphabet, with was perceived to have a strong religious and cultural symbolic value due to its close relation to the Greek alphabet, and especially with the uncial version of the latter which was used in early Gospel manuscripts (Coulmas, 1996, pp. 92-94; Daniels \& Bright, 1996, pp. 287-290). In more recent days, the substitution of Arabic abjad by Latin alphabet in Turkey in 1928 was an endogenous innovation which happened to be accurately planned and - in a large part - also personally developed by Kemal Atatürk himself, who strongly wanted to mark the modern, secular, and maybe a bit 'western' nature of the recently re-born nation (Coulmas, 1996, pp. 512-516; Daniels \& Bright, 1996, pp. 682-684). By doing so, the Kemalist ideology was fulfilling the whole project of the leader, which already had led to the reform of the Constitution in 1924, and which was now designing a brand-new educational system (Eisenstadt, 1984, p. 5). Generally speaking, in such cases a strong political power is often the main promoter of the writing system shift, which is often presented as an institutional act with mandatory effects (Arcangeli, 2007, p. 29; Olson, 1994). In many cases, this pedagogical and linguistic effort needed to be sustained by rich economic investments by the State, as happened in Kemal's script reform. Moreover, in the case of Turkey, the writing reform was followed by subsequent innovations that directly involved the language, like the 'Surname Law' of 1934, which completely reshaped Turkish traditional onomastic system 
into a more western one (Türköz, 2007, pp. 893-908). Anyway, many Turkish-speaking and local Muslim communities inside and outside Turkey did maintain, for quite a long time, a strong aversion against Kemal's writing reform, as happened for instance in Cyprus, Greece and Bulgaria (Tabak, 2017, pp. 20-25).

In some circumstances, the simultaneous use of two or more scripts appears to create a contact situation, that could perfectly be explained from a linguistic point of view. In these cases, functional interferences amongst different writing systems may occur, at least in a partial way, in a manner which strongly resembles that of inter-linguistic processes commonly observed in spoken languages (Unseth, 2005, pp. 19-42). For instance, in the case of ancient Cyprus we find many digraph inscriptions, mainly in Cyprus syllabic script and in Greek alphabet, where the scribes tend to reproduce the same text twice, by operating a kind of code switching that we could easily call script switching (Consani \& Negri, 2000, pp. 83-104; Consani, 2003). Normally, the Cypriote scribe, just as happens in verbal code switching, puts the lines of the more important of the two writing systems at the top of the inscription, and, by doing so, he determines, and visually shows, which one has to be considered the more prestigious script.

A quite similar process, of code mixing, can also occur in writing systems - in this case we could easily call it script mixing -, and it is commonly found, for example, in those Latin texts that contained single Greek words, not intended nor treated as loanwords, but rather still written in their original Greek alphabet. One more case is that of medieval scriptoria practices, where some scribes of 9th and 10th Century England, especially in lexicographic works, used to continuously switch between two different and parallel writing sets: namely, a late carolinian script for the texts in Latin language and, on contrary, an insular minuscule for the portions written in Old English language. Thus, for instance, in the case of the Latin-Old English glossary contained in Harley 3376 manuscript (10th Century A.D.), the scribe makes some significant mistakes in the Latin text, where he sometimes inserts typical insular - and so, Old English - shapes for letter $<\mathrm{r}>$ (ff. 85v, 79v, 88v), or for Latin diphthong 〈ae > as well (ff. 8v, 88v, 93v; cf. Oliphant, 1966; Cooke, 1997). Moreover, he constantly uses the insular shape also for the graece abbreviation, which he writes as $\langle\mathrm{g}\rangle$ in the whole glossary. If we can say that, by applying the normal rules of linguistic interference we could deduce that the scribe of Harley 3376 was a 'native insular' (i.e., Anglo-Saxon) scribe, who was more accustomed to writing Old English texts than Latin ones, and this simple linguistic fact could easily explain the 'direction' of his most recurrent writing mistakes.

One more effect of linguistic interference between different writing systems is what could be called script borrowing, which is a phenomenon that may have effect just over the morphological shape of the graphs, or also at a deeper graphemic level, and thus, it could change the function of single signs in the system (Daniels, 2006, pp. 7-24). Just as commonly happens in spoken languages, graphic borrowings may result to be less or more productive inside the recipient system. Thus, for example, the $\langle\mathrm{k}\rangle,\langle\mathrm{w}\rangle$ or $\langle\mathrm{x}\rangle$ graphemes, accepted into Italian from English, are now widely used in sub-standard varieties, such as juvenile jargon or SMS language, where <xké> is commonly used for perché 'because', or <xò> for però, 'but'. In some cases, only the external shape of single graphemes is borrowed, as 
happens for Latin uncial script, which is strongly dependent from the shape of the Greek uncial that was widely used in biblical and liturgical manuscripts, since 4th Century A.D. Some bilingual manuscripts, among others, show this similarity in a very significant way: for example, Codex Bezae, or the interlinear glossed text of Codex Boernerianus as well.

\section{Writing Systems Shift: A Brief Investigation of Its Causes, From 'Efficiency' to 'Identity'}

It's also important to investigate the reasons for writing system shift, especially if we consider that this whole changing process has been explained for a long time, from a linguistic point of view, simply in terms of achieving a 'better efficiency'. It is a fairly widespread opinion, in those cases where the replacement of a written code by a linguistic community takes place without a predominant external pressure, that the decision to adopt a new writing system is mainly due to a metalinguistic awareness of the fact that the previously used system was not really suitable for rendering the language of the community itself. Such an interpretation, combined with the fact that in most cases the newly adopted system is a Latin-based alphabet, has contributed to reinforcing the communis opinio according to which the alphabetic codes would represent a greater degree of perfection than those merely logographic (and phonographic of syllabic type), and that consequently there would be a linguistic 'universal' which naturally leads to the adoption of more advanced writing systems along a scale of perfection. A hypothesis which today is no longer widely shared, but which continues to circulate (Gelb, 1952; for early criticism, see Cardona, 1986).

The case, already mentioned above, of the progressive decay of the Aegean syllabic scriptures (i.e., Linear B, and classical Cypriot syllabary), during the first millennium B.C., has traditionally been interpreted as the death of a script system that was unsuitable for easily rendering the phonological sequences of the Greek language. In reality, Linear B had largely adapted its rules to the needs of that specific linguistic code. In addition, it is quite evident, both from a strictly graphematic and an ethnolinguistic point of view, how the Linear B actually had some structural qualities that made it paradoxically even more suitable than an alphabetic writing for the purpose for which it was used, that is, for the temporary fixing of the economic accounts of the Mycenaean palaces. In fact, for this purpose, two peculiar characteristics of that writing system revealed to be extremely functional, i.e., the marked tendency to tachygraphy, due to its syllabic nature and to the simplicity of the ductus of the most used signs, and, secondly, the presence of a specific repertoire of logographic glyphs, a restricted group which was clearly designed for the accounting record, and whose adoption concretely provided the possibility of easily identifying the nature of the goods recorded in the individual tablets, with extreme rapidity and at a simple glance. The main purpose of the logographic portion of the repertoire of the signs of Linear B, moreover, is implicitly confirmed by the fact that the subsequent classical Cypriot syllabary (strongly related, although not directly derived from Linear B) kept in use only the strictly phonographic portion of the system, given that - in the meanwhile - the context of use of the graphic code had radically changed, with the disappearance of the Mycenaean palatial accounting activities. 
One more issue has now to be addressed: who is the effective promoter of the writing system shift? The replacement of the Greek local alphabets with the new unified alphabet of Ionic origin had, as is widely known, important linguistic and political reflexes. Nevertheless, there were no significant linguistic reason that required such a replacement, and, on the other hand, the adoption of the Ionic alphabet forced many communities to undergo a laborious partial re-learning of the system, especially in the case of auxiliary signs or vowel glyphs. In this case, we perfectly know the promoter. The city of Athens, in 403 B.C., officially switched to the Ionic alphabet, wishing to revive the idea of the Naval League, to reactivate the economy, to rewrite the laws, and also to culturally differentiate itself from the Doric enemy - i.e., Sparta - and finally to propagate the idea of the Ionic ethnic unity. So, in this case we can say that it was an exogenous change, even if it wasn't promoted by a foreign entity. As a result, the diffusion of the Ionian alphabet somehow made the subsequent and parallel diffusion of the common Greek language, the koiné, much easier. The presence of a single, almost mythical figure of an 'adapter', who literally would have built the new Greek alphabet from its Phoenician predecessor, has been sustained, for instance, by Powell (1991), who proposed to identify him with the Homeric hero Palamedes, and who also thought that the specific scope of this invention was to write down the hexametric poems of the Greek tradition. Nevertheless, this theory presents many weak points, not only about the nature of the earliest Greek inscriptions, but also regarding the chronology of Palamedes, the Homeric hero who suddenly becomes, after four or five Centuries, the inventor of the alphabet (Speciale, 2003, pp. 33-41).

In some interesting cases, we can observe the maintenance of the same writing system, but with a parallel change in handwriting style. Between the 8th and 9th Century, the Carolingian reform decrees the rewriting of all manuscripts, with the new carolinian script, which - not surprisingly - was strongly inspired by classical models. Thus, many local European writings styles were abandoned: e.g., Merovingian, Beneventan, Visigoth, insular script, etc. In all these cases, at the basis of the code substitution there were certainly no linguistic needs, or any reading difficulties, but rather the clear will to propagate the new homogeneous cultural model, and the idea of a strong, rebuilt, and centralized Roman Empire (Reynolds \& Wilson, 1991).

At this point, we could usefully apply at our issue the hermeneutic concept of digraphia, as the graphic counterpart of diglossia (Dale, 1980; Unseth, 2005, p. 3). As a matter of fact, several cases are well known, in which a political and ethnic differentiation within a community is deliberately emphasized and strengthened through an artificial differentiation of written codes, leading to the situation in which two different writing systems are used for the same language, obviously without any linguistic motivation. A good example of this situation of digraphia is the Serbo-Croatian linguistic community, which adopts the Latin alphabet in (Catholic) Croatia, and the Cyrillic one in (Orthodox) Serbia; moreover, in Croatia the Latin alphabet was preceded by the local glagolitic script, which is still in use for liturgical purposes (Daniels \& Bright, 1996, pp. 769-772; Miklas et alii, 2000; Franolić \& Žagar, 2008). In the same way, Romanian speakers are now using the Latin alphabet in Romania (after various historical shifts), and the Cyrillic alphabet in Moldova (today 
voluntarily, due to a strong and recent desire for political self-determination; in 1863, instead, due to the imposition of Russian Empire). Moreover, in the Indian sub-continent the two modern variants of pracriti, namely Hindi (in the Indian Republic, mostly Hindu) and Urdu (in Pakistan, mostly Muslim), are written respectively in devanagari script (already used for Sanskrit) and in the local abjad, adapted from Arabic. One more case of digraphia was common among the Jewish communities in Europe. In fact, when they had to transcribe their respective European-based ethnolects (Fishman, 1997; Clyne, 2000) - such as German-based Yiddish, Judeo-Spanish, Judeo-Italian, etc. - they always chose the Hebrew writing, and rarely the Latin alphabet (Coulmas, 1996, pp. 570-572; Daniels \& Bright, 1996, pp. 727-742). A borderline case, then, is represented by the tiny Kashmir, where we can find a modified Arabic abjad for Muslims, a devanagari-like script for Hindus, the sarada script for the Pandits and, finally, the Latin writing, which is used for commercial relations with the West (Unseth, 2005, pp. 32-28).

A writing system shift, which occurs for political and ideological reasons, can obviously be quick and unexpected. This is the case of Turkey, that after using Arabic abjad for Centuries, suddenly decided to move to the Latin alphabet in 1928. With this choice, as we have seen, Kemal Atatürk wanted to strengthen both his own idea of a modern and secular country, and the same Turkish ethnic identity (Daniels \& Bright, 1996, p. 682). The great difficulties of spreading the new writing system were overcome, in this case, through an impressive educational effort. Moreover, Albania had preceded Turkey in 1908, with the Congress of Monastir. Anyway, some counter-cases could highlight the lack of success of writing reforms in the absence of a sufficiently influential promoter, or of a real identity necessity. Thus, for instance, in 1920s Somalia, osmanya script was artificially created in a cultured environment, in order to differentiate the local ethic identity both from the West and from the Arabs, but the new writing system was officially abandoned in 1973 (Coulmas, 1996, pp. 474-475; Daniels \& Bright, 1996, p. 580). In the same way, the reforms proposed by the Academy of the Romanian Language in the second half of the 19th Century, which aimed to adapt the spelling of many Romanian words to their ancient Latin counterparts, were no more fortunate: the Academy, for example, had proposed to write claue 'key' (cf. Latin clauis) instead of cheie, whereas the normal pronunciation of the Romanian word was - and then obviously continued to be $-[$ 'keje].

The significant case of the linguistic situation of the Balkans, since the end of the violent facts that occurred after year 1990, can perfectly confirm the central role of identity in writing system shift, as recently discussed in a study dedicated by Selvelli (2021) to the complex situation of Bulgaria, Serbia, and Croatia. It is not surprising, that similar dynamics can be found in any chronological period: e.g., in ancient Near East (Gösta, Overmann \& Payne, 2021), or in the already discussed example of classical Cyprus (Consani, 2003). As we can easily see, similar cases seem to confirm the general importance of identity perception in potentially - every process of writing system change (Coulmas, 2020).

\section{Shift and Ideology, and the Choice of the 'Less Adapt': The Case of Fraktur}

At the end of this brief discussion, a last single case could be quite noteworthy, as it may 
provide one more, and fairly striking evidence of the fact that writing system shifts do not necessarily occur from an old system to a new one, that is supposed to be 'more adapt' for rendering the language spoken by its community. At the beginning of the 20th Century, in Germany, the old-fashioned printing font called Fraktur had already lost its predominant position in favor of the more common western fonts. As a matter of fact, printed books in that particular script were just $42 \%$ of total in 1932. But Fraktur, being the last offspring of medieval littera textualis (or gothic script), was somehow perceived as visually more 'Germanic' than the common styles, which had derived from humanistic scripts, such as antiqua, or all bodonian fonts. So, Nazi regime decided to gradually facilitate, and then to definitively impose, the use of Fraktur writing, and the one of its handwritten counterpart as well (i.e., Kurrentschrift, or Sütterlin), for some purely ideological reasons. As a result, the amount of books printed in Fraktur reached the 60\% in 1936. Anyway, some years later, in the very middle of the $2^{\text {nd }}$ World War, the German Government suddenly, and unexpectedly, abandoned Fraktur in 1941, for mere motivations of communicative efficiency. In fact, at the time of the maximum expansion in the occupied territories, the officers of the Wehrmacht realized that Fraktur script, both in its printed and handwritten forms, was almost incomprehensible to all non-German-speaking troops. At the moment of the unexpected ban on the Fraktur, the script was surprisingly defined by the Nazi propaganda a 'Jewish writing', thus justifying its sudden abandonment also from a strong ideological point of view (Daniels \& Bright, 1996, pp. 765-768; Hartmann, 1998; Killis, 1999). The memorandum, dated January the $3^{\text {rd }} 1941$, was signed by Martin Bormann on behalf of the Führer (Bundesarchiv Koblenz, NS 6/334):

Die sogenannte gotische Schrift als eine deutsche Schrift anzusehen oder zu bezeichnen ist falsch. In Wirklichkeit besteht die sogenannte gotische Schrift aus Schwabacher Judenlettern. Genau wie sie sich später in den Besitz der Zeitungen setzten, setzten sich die in Deutschland ansässigen Juden bei Einführung des Buchdrucks in den Besitz der Buchdruckereien und dadurch kam es in Deutschland zu der starken Einführung der Schwabacher Judenlettern. Am heutigen Tage hat der Führer in einer Besprechung mit Herrn Reichsleiter Amann und Herrn Buchdruckereibesitzer Adolf Müller entschieden, dass die Antiqua-Schrift künftig als Normal-Schrift zu bezeichnen sei. Nach und nach sollen sämtliche Druckerzeugnisse auf diese Normal-Schrift umgestellt werden. Sobald dies Schulbuchmässig möglich ist, wird in den Dorfschulen und Volksschulen nur mehr die Normal-Schrift gelehrt werden. Die Verwendung der Schwabacher Judenlettern durch Behörden wird künftig unterbleiben; Ernennungsurkunden für Beamte, Straßenschilder u. dergl. werden künftig nur mehr in Normal-Schrift gefertigt werden.

[It is wrong to regard or to describe the so-called Gothic script as a German script. In reality, the so-called Gothic script consists of Schwabach Jew letters. Just as they later took control of the newspapers, upon the introduction of printing the Jews residing in Germany took control of the printing presses and thus in Germany the Schwabach Jew letters were forcefully introduced. Today the Führer, talking with Herr Reichsleiter Amann and Herr Book Publisher Adolf Müller, has decided that in the future the Antiqua script is to be described as normal script. All printed materials are to be gradually 
converted to this normal script. As soon as is feasible in terms of textbooks, only the normal script will be taught in village and state schools. The use of the Schwabach Jew letters by officials will in future cease; appointment certifications for functionaries, street signs, and so forth will in future be produced only in normal script].

So, in the case of this particular script, both its revival at the beginning of the Century, and its sudden disgrace in 1941, should have been motivated by many reasons, but surely not by any 'efficiency' issue in terms of adaptation to the underlying language. And the main reason was - perhaps - just identity.

\section{Some Possible Conclusions}

At this point, we could say that the various cases of written code shift, which we have observed so far, easily demonstrate the strong markedness of the shifting process, but also the need for the presence either of an exogenous and authoritative promoter, or of an equally cogent endogenous motivation, depending on the fundamental role of the political, social and identity issues that underlie any replacement of written code, and which can actually determine their fortune. This strongly reminds to a universal linguistic tendency, which was already noticed by Fasold (1984, p. 248), who demonstrated that, generally speaking, group identity issues should be considered to be the strongest motivations for a successful language shift process. Thus, for instance, a really interesting case of strong interconnection between script shift and identity, concerning Taiwan, has been recently presented and discussed by Karen Huang (2019); moreover, similar observations arise from the example of Berber (cf. Soulaimani, 2016), and the case of Fraktur, described above in this paper, is quite similar.

On the other hand, functional adequacy in absolute terms does not seem to be a good explanation for replacing a written code; therefore, we simply can't consider a graphic system more perfect than another, and it is difficult to support the idea that in the history of writing systems there is an evolution that proceeds from logographic systems to alphabetic ones, through the syllabaries. The examples of a return to a system which was considered 'less perfect', from an 'already alphabetic' one, seem to confirm this hypothesis: e.g., Northern Italic and Iberian semi-syllabaries, the long resistance of the Cypriot syllabary, Ethiopian writing, Indian systems of Aramaic derivation, etc. From a strictly linguistic point of view, then, all the observed cases are perfectly understandable in the light of the theory of linguistic interference (Unseth, 2005, pp. 19-42).

New needs may possibly require the adoption of a completely new writing system, but this adoption is per se extremely expensive, and traumatic, so that the normal response to new needs remains the improvement of the already adopted system, or an extremely slow replacement where the two writing systems coexist in use for a long period of time. On this topic, we can easily confirm the observations by Baines, Bennet \& Houston (2008, p. 149):

Normally the disappearance of writing systems goes hand-in-hand with the disintegration of complex societies, dynastic change caused by a foreign invasion, language shift, or a combination of these factors.

The only innovations, that have found an effective historical realization, have been those 
promoted by a strong authority: e.g., by an influential political or religious subject, or a powerful group representing homogeneous economic and commercial interests; more rarely, it was a group of intellectuals, or a cultural movement. Moreover, the identity of the promoting subject has often proved to be much more important and decisive than the linguistic need (real or fictitious) of the speaking community. The writing system that imposes itself is generally a 'prestigious' script, and the 'graphic fidelity', which has been thus obtained, becomes a powerful lever of identity and of ethnic propaganda as well, according to general trends of linguistic interference (cf. Bassetti, 2013; Gnanadesikan, 2021).

Therefore, we could conclude that the replacement of a written code seems to be nothing but the result of the encounter between: (i) a strong request of the linguistic community, in terms of identity strengthening (mostly endogenous), and (ii) a strong promoter of the innovation itself (often - but not always - exogenous), with the same scope of identity strengthening.

\section{References}

Arcangeli, M. (2007). Lingua e identità. Roma: Meltemi.

Baines, J., Bennet, J., \& Houston, S. (2008). The Disappearance of Writing Systems: Perspectives on Literacy and Communication. London: Equinox.

Banfi, E., \& Grandi, N. (2012). Lingue d'Europa. Elementi di storia e di tipologia linguistica. Roma: Carocci.

Baroni, A. (2011). Alphabetic vs. non-alphabetic writing: linguistic fit and natural tendencies. Rivista di Linguistica, 23(2), 127-159.

Bassetti, B. (2013). Bilingualism and Writing Systems. In T. K. Bhatia, \& C. Ritchie (Eds.), The Handbook of Bilingualism and Multilingualism (pp. 649-670). Malden, MA: Wiley-Blackwell.

Cardona, G. R. (1986). Storia universale della scrittura. Milano: Mondadori.

Cardona, G. R. (1991). Antropologia della scrittura. Torino: Einaudi.

Chadwick, J. (1990). Linear B and Related Scripts. Berkeley, CA: University of California Press.

Clyne, M. (2000). Lingua Franca and Ethnolects in Europe and Beyond. Sociolinguistica, 14(1), 83-89. https://doi.org/10.1515/9783110245196.83

Consani, C. (2003). Sillabe e sillabari fra competenza fonologica e pratica scrittoria. Alessandria: Edizioni dell'Orso.

Consani, C., \& Negri, M. (2000). Le scritture egee. In M. Negri M. (Ed.), Alfabeti (pp. 83-104). Colognola ai Colli: Demetra.

Cooke, J. (1997). Worcester Books and Scholars, and the Making of the Harley Glossary (British Library MS. Harley 3376). Anglia, 115, 441-468. 
https://doi.org/10.1515/angl.1997.115.4.441

Cotticelli-Kurras, P., \& Rizza, A. (2017). Variation within and among writing systems. Wiesbaden: Reichert. https://doi.org/10.29091/9783954905546

Coulmas, F. (1996). The Blackwell Encyclopedia of Writing Systems. Oxford: Oxford University Press. https://doi.org/10.1002/9781118932667

Coulmas, F. (2003). Writing Systems: An Introduction to Their Linguistic Analysis. Cambridge: Cambridge University Press. https://doi.org/10.1017/CBO9781139164597

Coulmas, F. (2020). Writing and identity. Written Language \& Literacy, 23(2), 180-193. https://doi.org/10.1075/wll.00039.cou

Crystal, D. (2002). Language Death. Cambridge: Cambridge University Press. https://doi.org/10.1017/s0041977x01630167

Dale, I. R. H. (1980). Digraphia. International Journal of the Sociology of Language, 26, 5-13. https://doi.org/10.1515/ijsl.1980.26.5

Daniels, P. T. (2006). On Beyond Alphabets. Written Language and Literacy, 9(1), 7-24. https://doi.org/10.1075/wll.9.1.03dan

Daniels, P. T. (2018). An exploration of writing. Bristol: Equinox.

Daniels, P. T., \& Bright, W. (1996). The World's Writing Systems. New York, NY / Oxford: Oxford University Press.

Ehlich, K., Coulmas, F., \& Graefen, G. (1996). A Bibliography on Writing and Written Language. Berlin: Mouton de Gruyter.

Eisenstadt, S. N. (1984). The Kemalist Regime and Modernization: Some Comparative and Analytical Remarks. In J. Landau (Ed.), Atatürk and the Modernization of Turkey (pp. 3-16). Boulder (CO): Westview Press.

Fasold, R. (1984). The Sociolinguistics of Society. Oxford / New York, NY: Blackwell.

Fishman, J. (1997). Language and ethnicity: The view from within. In F. Coulmas (Ed.), The Handbook of Sociolinguistics (pp. 327-343). Oxford / New York, NY: Blackwell. https://doi.org/10.1002/9781405166256.ch20

Franolić, B., \& Žagar, M. (2008). A Historical Outline of Literary Croatian and the Glagolitic Heritage of Croatian Culture. Zagreb: Erasmus.

Gelb, I. J. (1952). A Study of Writing: The Foundations of Grammatology. London: Routledge.

Ghinatti, F. (1999). Alfabeti greci. Torino: Paravia.

Gnanadesikan, A. E. (2021). S 1 : The Native Script Effect. In Y. Haralambous (Series Ed.), Grapholinguistics and Its Applications: Vol. 4a. Grapholinguistics in the 21st Century - 2020. Proceedings (pp. 213-233). Brest: Fluxus. https://doi.org/10.36824/2020-graf-gnan 


\section{Macrothink}

International Journal of Linguistics

ISSN 1948-5425

2022, Vol. 14, No. 1

Gösta, G., Overmann, K. A., \& Payne, A. (2021). Signs - sounds - semantics. Nature and transformation of writing systems in the Ancient Near East. Tecklenburg: Ugarit Verlag.

Gusmani, R. (1987). Interlinguistica. In R. Lazzeroni (Ed.), Linguistica storica (pp. 87-114). Roma: Carocci.

Harmann, H. (2002). Geschichte der Schrift. München: Beck. https://doi.org/10.17104/9783406622700

Hartmann, S. (1998). Fraktur oder Antiqua. Der Schriftstreit von 1881 bis 1941. Frankfurt am Main: Lang.

Huang, K. (2019). Language ideologies of the transcription system Zhuyin fuhao: a symbol of Taiwanese identity. Writing Systems Research, 11(2), 159-175. https://doi.org/10.1080/17586801.2020.1779903

Iannàccaro, G. (2005). La scrittura delle lingue. Milano: CUEM.

Joseph, J. E. (2004). Language and Identity. National, Ethnic, Religious. New York, NY: Palgrave MacMillan.

Karan, M. E. (2011). Understanding and Forecasting Ethnolinguistic Vitality. Journal of Multilingual and Multicultural Development, 32(2), 137-149. https://doi.org/10.1080/01434632.2010.541916

Killis, C. (1999). Die Antiqua-Fraktur-Debatte um 1800 und ihre historische Herleitung. Wiesbaden: Harrassowitz.

Labov, W. (2001). Principles of Linguistic Change. Oxford / New York, NY: Blackwell.

McLean, B. H. (2002). An Introduction to Greek Epigraphy of the Hellenistic and Roman Periods from Alexander the Great down to the Reign of Constantine (323 B.C.-A.D. 337). Ann Arbor, MI: University of Michigan Press. https://doi.org/10.3998/mpub.23012

Meletis, D. (2020). The Nature of Writing. A Theory of Grapholinguistics. In Y. Haralambous (Series Ed.), Grapholinguistics and Its Applications: Vol. 3. Brest: Fluxus. https://doi.org/10.36824/2020-meletis

Miklas, H. (2000). Glagolitica. Wien: Österreichische Akademie der Wissenschaften.

Mufwene, S. (2008). Language evolution: Contact, competition and change. London: Continuum. https://doi.org/10.5040/9781350934078

Neef, M. (2015). Writing systems as modular objects: proposals for theory design in grapholinguistics. Open Linguistics, 1, 708-721. https://doi.org/10.1515/opli-2015-0026

Oliphant, R. T. (1966). The Harley Latin-Old English Glossary. Edited from British Museum ms. Harley 3376. The Hague: Mouton.

Olson, D. R. (1994). The World on Paper. The Conceptual and Cognitive Implications of Writing and Reading. Cambridge: Cambridge University Press. 
Powell, B. B. (1991). Homer and the Origin of the Greek Alphabet. Cambridge. Cambridge University Press.

Reynolds, L. D., \& Wilson, N. G. (1991). Scribes and Scholars: A Guide to the Transmission of Greek and Latin Literature. Oxford: Clarendon Press.

Rogers, H. (2005). Writing Systems: A Linguistic Approach. Oxford: Blackwell.

Romaine, S. (1994). Language in Society: An Introduction to Sociolinguistics. Oxford: Oxford University Press.

Rosenberg, A. L. (1979). The Hardest Natural Languages. Lingvistica Investigationes, 3(2), 323-339.

Sampson, G. R. (2016). Typology and the study of writing systems. Linguistic Typology, 20(3), 561-567.

Sanga, G. (2009). Antropologia della scrittura: origini e forme. In M. Mancini, \& B. Turchetta (Eds.), Scrittura e scritture: le figure della lingua (pp. 13-66). Roma: Il Calamo.

Selvelli, G. (2021). The Alphabet of Discord The Ideologization of Writing Systems on the Balkans since the Breakup of Multiethnic Empires. Stuttgart: Ibidem.

Soulaimani, D. (2016). Writing and rewriting Amazigh/Berber identity: Orthographies and language ideologies. Writing Systems Research, 8(1), 1-16. https://doi.org/10.1080/17586801.2015.1023176

Speciale, N. (2003). Omero e l'origine dell'alfabeto greco. Pan, 21, 33-41.

Tabak, H. (2017). The Kosovar Turks and Post-Kemalist Turkey: Foreign Policy, Socialization and Resistance. London: Tauris. https://doi.org/10.5040/9781350988842

Thomason, S. G. (2001). Language Contact: An Introduction. Edinburgh: Georgetown University Press.

Thomason, S. G., \& Kaufman, T. (1988). Language Contact, Creolization, and Genetic Linguistics. Berkeley, CA: University of California Press.

Tsui, A., \& Tollefson, J. (2007). Language Policy, Culture, and Identity in Asian Contexts. London: Erlbaum.

Türköz, M. (2007). Surname narratives and the state-society boundary: Memories of Turkey's family name law of 1934. Middle Eastern Studies, 43(6), 893-908. http://dx.doi.org/10.1080/00263200701568253

Unseth, P. (2005). Sociolinguistic Parallels Between Choosing Scripts and Languages. Written Language and Literacy, 8(1), 19-42. https://doi.org/10.1075/wll.8.1.02uns

Valeri, V. (2001). La scrittura. Storia e modelli. Roma: Carocci.

Vygotsky, L. (1978). Mind in Society. Cambridge, MA: Harvard University Press. 


\section{Macrothink}

International Journal of Linguistics

ISSN 1948-5425 2022, Vol. 14, No. 1

Witzel, M. (2001). Autochthonous Aryans? The Evidence from Old Indian and Iranian Texts. Electronic Journal of Vedic Studies, 7(3), 1-115. https://doi.org/10.11588/xarep.00000118

Woodard, R. D. (1997). Greek Writing from Knossos to Homer: A Linguistic Interpretation on the Origin of Greek Alphabet and the Continuity of Ancient Greek Literacy. Oxford: Oxford University Press.

Wurm, S. (1991). Language Death and Disappearance: Causes and Circumstances. Diogenes, 153(39), 1-18.

\section{Copyrights}

Copyright for this article is retained by the author(s), with first publication rights granted to the journal.

This is an open-access article distributed under the terms and conditions of the Creative Commons Attribution license (http://creativecommons.org/licenses/by/4.0/) 